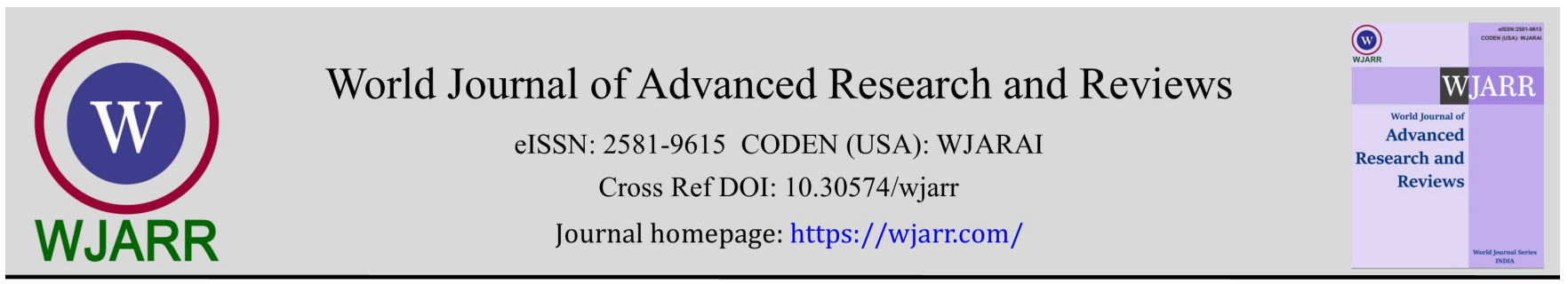

(RESEARCH ARTICLE)

\title{
Effects of osmo-priming on germination, growth and green pod yield of okra [Abelmoschus esculentus (L.) Moench] at Luyengo, Middleveld of Eswatini
}

\author{
Sibeko Nomkhosi B, Mzwandile Mabuza and Tamado Tana * \\ Department of Crop Production, Faculty of Agriculture, University of Eswatini, P.O. Luyengo, M 205, Eswatini.
}

World Journal of Advanced Research and Reviews, 2021, 11(01), 029-038

Publication history: Received on 25 April 2021; revised on 04 July 2021; accepted on 08 July 2021

Article DOI: https://doi.org/10.30574/wjarr.2021.11.1.0248

\begin{abstract}
Okra is a nutritious summer vegetable crop in Eswatini. However, it has slow and uneven germination. Seed pre-sowing treatment through osmo-priming can enhance the germination, growth and yield of okra. Thus, laboratory and field experiments were conducted at Luyengo, Middleveld of Eswatini in 2019/2020 cropping season to determine the effect of osmo-priming on germination, growth and yield of okra. Treatments included priming of seeds with Polyethylene glycol (PEG) concentration of 5\%,10\%,15\%, and 20\% and unprimed control. Completely randomized design was used for the laboratory experiment and randomized complete block design was used for the field experiment. Results showed significant $(\mathrm{p}<0.01)$ effect of seed priming on the germination index, mean germination time and final germination percentage of okra seeds. Significantly the highest germination index (5.2) and final germination percentage (66) were recorded in priming with 15\% PEG. Similarly, seeds priming with 15\% PEG resulted in significantly the highest number of leaves per plant (12.07), leaf area index (1.49), canopy height (120.9 cm), and number of branches per plant (8.13). Moreover, okra seeds primed in 15\% PEG resulted in the highest pod length and total green pod yield (2009.8 $\left.\mathrm{kg} \mathrm{ha}^{-1}\right)$. Thus, it can be concluded that seed priming with 15\% PEG is the most effective in improving the germination, growth and yield of okra in the study area.
\end{abstract}

Keywords: Germination index; Germination percentage; Okra; Osmo-priming; Polyethylene glycol

\section{Introduction}

Okra [Abelmoschus esculentus (L.) Moench] is a common vegetable crop grown under tropical and subtropical conditions. Being native to tropical Africa (extending from Ethiopia to the Sudan), it is valued vegetable in many countries [1]. Okra has tender delicious fruits and is a good source of essential vitamins (e.g., Vitamin C) and minerals such as calcium, phosphorus, magnesium and iron. It possesses high nutritive value, which is higher than tomatoes, eggplant and most cucurbits except bitter gourds [2]. Okra pods are a good source of flavonoid antioxidants like beta carotene, xanthein and lutein [3]. Okra is also valuable with regards to anti-carcinogenicity, human immunity promotion, ageing prevention and health-care [4].

However, the slow and uneven germination of okra seed is the main problem in its production [5]. The percentage of seed germination of okra is relatively low, due to occurrence of hard seededness [6]. The percentage of hardseedness varies among the cultivars with some cultivars not having hardseedness or having a low percentage of hard seeds that doesn't impose any impedance on their germination, whereas for other cultivars the high percentage of hard seeds does not allow them to germinate, or allows only for low germination percentage [7].

Seed priming is pre-sowing treatment used as a technique to enhance seed performance, notably with respect to rate and uniformity of germination, thereby improving seedling stand and enabling better crop establishment [8]. It is a

\footnotetext{
* Corresponding author: Tamado Tana

Department of Crop Production, Faculty of Agriculture, University of Eswatini, P.O. Luyengo, M 205, Eswatini.

Copyright $(2021$ Author(s) retain the copyright of this article. This article is published under the terms of the Creative Commons Attribution Liscense 4.0.
} 
simple, low cost and effective approach for early seedling growth and yield under stressed and non-stressed conditions. Priming triggers the synthesis or activation of some enzymes that catalyze the mobilization of storage reserves in seed, while endosperm weakens by hydrolase activities. Priming may also increase resistance to abiotic stresses such as drought [9].

There are various types of seed priming, in one type water penetrate freely into seed which is called hydropriming while in other type seed hydration is controlled. If controlled hydration is achieved through the addition of solute to water then it is called osmopriming or if a solid matrix is used to provide controlled seed hydration then it is called solid matrix priming [10]. Osmopriming strengthens the antioxidant system and increases seed germination potential, resulting in an increased stress tolerance in germinating seeds [11]. Osmopriming with polyethylene glycol (PEG) improves seed germination, emergence, and seedling establishment of several crops especially under stress conditions and also enhances general crop performance. For instance, improvements in germination and seedling establishment were noted for rice (Oryza sativa L.) under drought after seed osmopriming with PEG [12]. Similarly, osmopriming cumin seeds $(-0.8$ and -1.2 Mpa of PEG 6000 solution) accelerated seed germination to a largest extent and improved the germination rate and uniformity under drought stress [13].

Okra is an important short duration vegetable crop in Eswatini. However, the yield of the crop is low partly due to erratic and poor germination of the seeds. Sikhondze and Ossom [14] recommended hydro priming of okra seeds for 24 hours before planting. Similarly, Rahman et al. [15] reported maximum absolute growth rate of okra at -1.2Mpa osmotic potential with PEG-8000. Since the response of seed to priming is affected by priming duration [16], osmotic potential of priming solution [17], priming agent [18], oxygen supply to seed [19], and cultivars [7], there is a need to determine an appropriate concentration of priming medium for okra.

Thus, this study was undertaken to determine the effects of concentrations of polyethylene glycol (PEG) on germination, growth and green pod yield of okra.

\section{Material and methods}

\subsection{Laboratory experiment}

\subsubsection{Treatments and the experimental design}

The treatments consisted of four concentrations of Polyethylene glycol 400 (PEG 400), i.e. 5\%, 10\%, 15\% and 20\% and unprimed dry seeds. Completely randomized design with three replications for each treatment was used.

\subsubsection{Experimental procedure}

The experiment was conducted in the Agronomy laboratory of Crop Production Department which had an average temperature of $23{ }^{\circ} \mathrm{C}$. The PEG was diluted in distilled water in the ratios of 5:95, 10:90, 15:85 and 20:80 to obtain 5\%, $10 \%, 15 \%$ and $20 \%$ PEG concentrations, respectively. The seeds were soaked in 10 ML of different concentrations of PEG for 24 hours in an incubator adjusted at $25^{\circ} \mathrm{C}$ under dark condition. After priming, the seeds were rinsed with distilled water and surface-dried on moisture absorbent cotton sheet and dried to their near-original moisture content at room temperature. After drying, 50 seeds were put in each sterilized petri-dish with a diameter of $12 \mathrm{~cm}$ for the germination test. The treatments were assigned completely at random in the petri-dishes in three replications each. Counts of germinated seeds were made daily from 14:00-16:00 hours starting from the second day after putting the seeds in the petri-dishes until there was no further germination on day 12. Same amount of distilled water was applied to keep the seeds in the petri-dishes moist.

\subsubsection{Data collected}

Final Germination Percentage (FGP) was determined as described in ISTA [22].

$$
\text { FGP }=\frac{\text { Total number of normal seeds germinated }}{\text { Total number of seeds sown }} \times 100
$$

Similarly, the Germination Index (GI) and Mean Germination Time (MGT) were determined as described by Ellis and Roberts [23]. 


$$
\begin{gathered}
\text { GI }=\frac{\text { No.of germinated seeds }}{\text { Days of first count }}+\ldots+\frac{\text { No. of germinated seeds }}{\text { Days of final count }} \\
M G T=\frac{\Sigma(D n)}{\Sigma n}
\end{gathered}
$$

Where $n$ is the number of seeds that germinated on day $D$ and $D$ is a number of days counted from the beginning of germination.

\subsection{Field experiment}

\subsubsection{Site description}

The field experiment was conducted at Luyengo, the University of Eswatini, Faculty of Agriculture, Crop production farm. Luyengo is located in the Middleveld agro-ecological zone of Eswatini, at longitude of $31.10^{\circ}$ East and latitude of $26.334^{\circ}$ south and has an altitude of $750 \mathrm{~m}$ above sea level [20]. The site has an average annual rainfall of $980 \mathrm{~mm}$ with most rain occurring between October and April. The mean annual temperature is $18{ }^{\circ} \mathrm{C}$ with average winter temperature of $15^{\circ} \mathrm{C}$ and with average summer temperature of $27^{\circ} \mathrm{C}$. The average temperature and total rainfall during the growing season of December 2019 to April 2020 were $22.4{ }^{\circ} \mathrm{C}$ and $449.2 \mathrm{~mm}$, respectively. The soil type of the experimental site is the Malkerns M set soil series clay loam to sandy loam Oxisols mostly with acidic soil pH [21].

\subsubsection{Treatments and the experimental design}

The treatments consisted of four concentrations of Polyethylene glycol 400 (PEG 400), i.e. 5\%, 10\%, 15\% and 20\% and unprimed dry seeds. Randomized Complete Block Design with three replications for each treatment was used for the experiment.

\subsubsection{Experimental field management}

The experimental field was ploughed and disked to a fine tilth with tractor and the plots were levelled manually. According to the design, a field layout was made and each treatment was assigned randomly to the experimental units within a block. The gross size of each plot was $3.6 \mathrm{~m} \times 3.6 \mathrm{~m}\left(12.96 \mathrm{~m}^{2}\right)$ consisting of four rows in inter-row spacing of $90 \mathrm{~cm}$ and intra-row spacing of $25 \mathrm{~cm}$. The outermost one row on both sides of each plot was considered as border and not used for data collection to avoid border effects. Thus, the net plot was 2 rows $\times 0.9 \mathrm{~m} \times 3.6 \mathrm{~m}\left(6.48 \mathrm{~m}^{2}\right)$. After priming the seeds at their respective concentration of PEG, the seeds were dried to initial moisture content at room temperature and then three okra seeds were sown per planting station at a planting depth of about $2.5 \mathrm{~cm}$. At planting, fertilizer $2: 3: 2(22)$, consisting of $6.3 \% \mathrm{~N}, 9.4 \% \mathrm{P}$ and $6.3 \% \mathrm{~K}$, was applied at the rate of $300 \mathrm{~kg} \mathrm{ha}^{-1}$. Limestone ammonium nitrate (LAN) containing 28\% nitrogen was side dressed four weeks after emergence of okra plants at a rate of $200 \mathrm{~kg}^{-1}$. Thinning to one plant per station was done three weeks after emergence. Weeds were controlled manually using hand hoe. As the experiment was a rain-fed, no supplemental irrigation was applied.

\subsubsection{Data collected}

The numbers of leaves were counted at 50\% flowering stage from five randomly selected plants from each of the net plot and the number was averaged on per plant basis. The leaf area was determined using the cork borer method from three randomly selected plants per net plot at 50\% flowering stage following the procedure described by Edje and Ossom [20] and the leaf area was averaged on per plant basis. Then, the leaf area index was determined by dividing the leaf area $\left(\mathrm{cm}^{2}\right)$ per plant by the ground area occupied by each plant $(90 \mathrm{~cm} \times 25 \mathrm{~cm})$. The number of branches was determined by counting the branches on the main stem from three randomly taken plants from each net plot at last harvesting and was averaged on per plant basis. Canopy height was measured using a calibrated stake, measuring from the surface of the soil to the highest leaf subtended by the plant. Ten plants were picked at random from the net plot at the last harvesting stage and the height was averaged on per plant basis. Similarly, the length of pod bearing zone was determined by measuring the length from the point of beginning of the pod to the point where pod formation ends from randomly taken ten plants from the net plot and then the length was averaged on per plant basis.

The green pods from the net plot were harvested three times at a weekly interval. After each harvest, the lengths and widths of the ten randomly taken green pods from each net plot were measured using ruler and a Vernier caliper, respectively, and averaged on per plant basis. Yield of green pods per net plot was determined at each harvest. Then, the total green pod yield per hectare was determined by summed up the yield of all the three harvests per net plot and was expressed in $\mathrm{kg} \mathrm{ha}^{-1}$ 


\subsection{Data analysis}

Data from both experiments were subjected to analysis of variance using GenStat 15 ${ }^{\text {th }}$ Edition [24]. Significantly different treatment means were separated using the least significant difference (LSD) test at 5\% level of significance.

\section{Results}

\subsection{Germination characteristics}

There was a highly significant $(\mathrm{p}<0.05)$ effect of priming with different concentrations of PEG on the germination index and final germination percentage of okra seeds (Table 1). Significantly the highest germination indices of 5.63 and 5.2 were recorded in priming the seeds with 5\% PEG and 15\% PEG, respectively (Table 1). Similarly, the highest final germination percentage (66) was recorded in priming with 15\% PEG. In contrast, the lowest germination index (3.82) and final germination percentage (46) were recorded from the control (no priming) (Table 1).

The mean germination time was significantly $(\mathrm{p}<0.05)$ affected by priming with different concentrations of PEG (Table 1). The shortest mean germination time (4.69 days) was recorded for the control while the PEG concentrations significantly delayed the mean germination time ranging from 6.04 days to 6.79 days (Table 1).

Table 1 Effects of priming with different concentrations of PEG on germination characteristics of okra seeds

\begin{tabular}{|l|c|c|c|}
\hline PEG concentration & Germination index & Final germination $\%$ & Mean germination time (days) \\
\hline Control (no priming) & $3.82 \mathrm{~b}^{\dagger}$ & $46.0 \mathrm{c}$ & $4.69 \mathrm{~b}$ \\
\hline $5 \%$ PEG & $5.63 \mathrm{a}$ & $64.7 \mathrm{ab}$ & $6.04 \mathrm{a}$ \\
\hline $10 \%$ PEG & $4.18 \mathrm{~b}$ & $56.0 \mathrm{~b}$ & $6.13 \mathrm{a}$ \\
\hline $15 \%$ PEG & $5.20 \mathrm{a}$ & $66.0 \mathrm{a}$ & $6.79 \mathrm{a}$ \\
\hline $20 \%$ PEG & $4.27 \mathrm{~b}$ & $60.0 \mathrm{ab}$ & $6.70 \mathrm{a}$ \\
\hline LSD $(0.05)$ & 0.699 & 9.11 & 1.14 \\
\hline Significance & $* *$ & $* *$ & $*$ \\
\hline
\end{tabular}

LSD (0.05) = Least Significant Difference at $5 \%$ level; ${ }^{\dagger}$ Means in columns followed by the same letters are not significantly different at $5 \%$ level of significance according to LSD test.; ${ }^{*}$ And ${ }^{* *}=$ Significant at $5 \%$ and $1 \%$ level of probability, respectively

\subsection{Growth parameters}

\subsubsection{Number of leaves, leaf area index and number of branches}

The number of leaves and leaf area index per plant at flowering were significantly $(\mathrm{p}<0.05)$ affected by the priming treatments (Table 2).

Table 2 Effects of priming with different concentrations of PEG on growth parameters of okra

\begin{tabular}{|c|c|c|c|}
\hline PEG concentration & Number of leaves per plant & Leaf area index & Number of branches per plant \\
\hline Control & $9.53 \mathrm{~b}^{\dagger}$ & $1.05 \mathrm{~b}$ & $5.33 \mathrm{~b}$ \\
\hline $5 \%$ PEG & $9.47 \mathrm{~b}$ & $1.04 \mathrm{~b}$ & $5.33 \mathrm{~b}$ \\
\hline $10 \%$ PEG & $11.13 \mathrm{a}$ & $1.27 \mathrm{ab}$ & $5.67 \mathrm{~b}$ \\
\hline $15 \%$ PEG & $12.07 \mathrm{a}$ & $1.49 \mathrm{a}$ & $8.13 \mathrm{a}$ \\
\hline $20 \%$ PEG & $9.53 \mathrm{~b}$ & $1.08 \mathrm{~b}$ & $5.33 \mathrm{~b}$ \\
\hline LSD (0.05) & 1.527 & 0.240 & 0.908 \\
\hline Significance & $*$ & $*$ & $* *$ \\
\hline
\end{tabular}

LSD (0.05) = Least Significant Difference at 5\% level; † Means in columns followed by the same letters are not significantly different at $5 \%$ level of significance according to LSD test; * And ${ }^{* *}=$ Significant at $5 \%$ and $1 \%$ level of probability, respectively. 
The highest number of leaves (12.07) was recorded in priming with 15\% PEG and it was statistically at par with priming in 10\% PEG (11.13). Similarly, significantly the highest leaf area index (1.49) and number of branches per plant (8.13) were recorded in priming with 15\% PEG followed by priming in 10\% PEG. In contrast, the other concentrations and the control gave significantly lower number of leaves, leaf area index and number of branches of okra (Table 2).

\subsubsection{Canopy height and length of pod bearing zone}

The canopy height at the third harvest was highly significantly $(\mathrm{P}<0.05)$ affected by the priming treatments (Figure 1$)$. Significantly the highest canopy height $(120.9 \mathrm{~cm})$ was recorded in priming with $15 \%$ PEG while the other concentrations and unprimed control had significantly lower canopy height. On the other hand, the effect of priming with PEG had no significant effect on length of pod bearing zone of okra (Figure 1). The length of pod bearing zone ranged from $29.5 \mathrm{~cm}$ in priming with PEG at $5 \%$ to $33.20 \mathrm{~cm}$ in priming with $15 \%$ PEG (Figure 2).

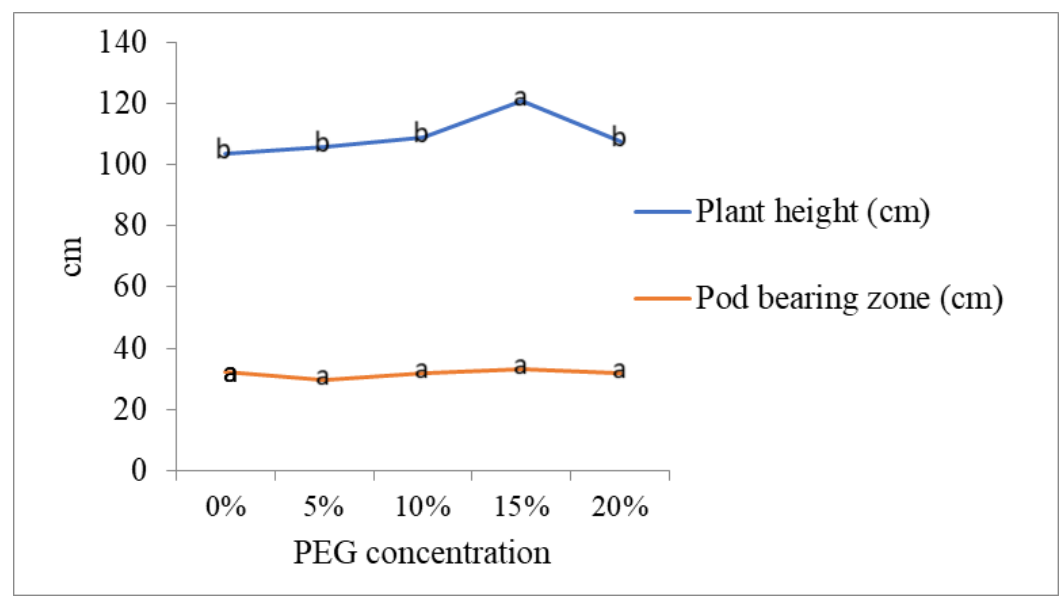

Figure 1 Canopy height and length of pod bearing zone of okra in response to priming with different concentrations of PEG

Means in lines followed by the same letter are not significantly different at $5 \%$ level of significance according to Least Significant Difference (LSD) test.

\subsection{Yield components and yield}

\subsubsection{Pod length}

There was highly significant $(\mathrm{P}<0.01)$ effect of priming with $\mathrm{PEG}$ on the length of pods in first and second harvests (Figure 2). Priming with 15\% PEG resulted in significantly the highest pod length of $11.73 \mathrm{~cm}$ and $13.27 \mathrm{~cm}$ at first and second harvests, respectively (Figure 2).

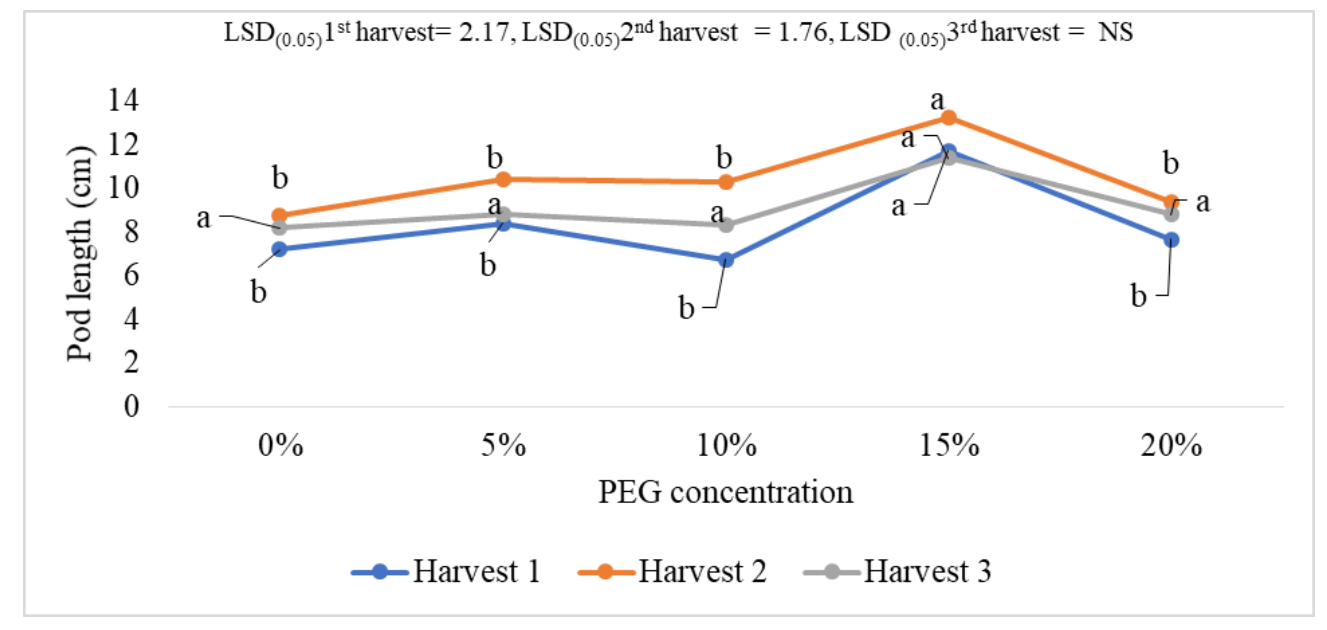

Figure 2 Average pod length $(\mathrm{cm})$ of okra from the first to third harvests in response to priming with different concentrations of PEG 
In contrast, the other treatments gave significantly lower pod lengths at both harvests. In the second harvest, the unprimed control had the lowest pod length of $8.73 \mathrm{~cm}$. On the other hand, the effect of priming with PEG had no significant effect on pod length at third harvest (Figure 2).

However, priming with 15\% PEG had the highest pod length of $11.4 \mathrm{~cm}$ (Figure 2). In general, pods in the second harvest had higher length than in the first and the third harvest.

Means in lines for same harvest followed by the same letter are not significantly different at $5 \%$ level of significance according to Least Significant Difference (LSD) test.

\subsubsection{Pod width}

There was no significant difference among the pod widths obtained from the first to the third harvests. In general, the pod width ranged from 2.1 to $2.4 \mathrm{~cm}$ (Figure 3). Priming with 15\% PEG and the control resulted in relatively higher pod widths at all the three harvests as compared to the other treatments (Figure 3).

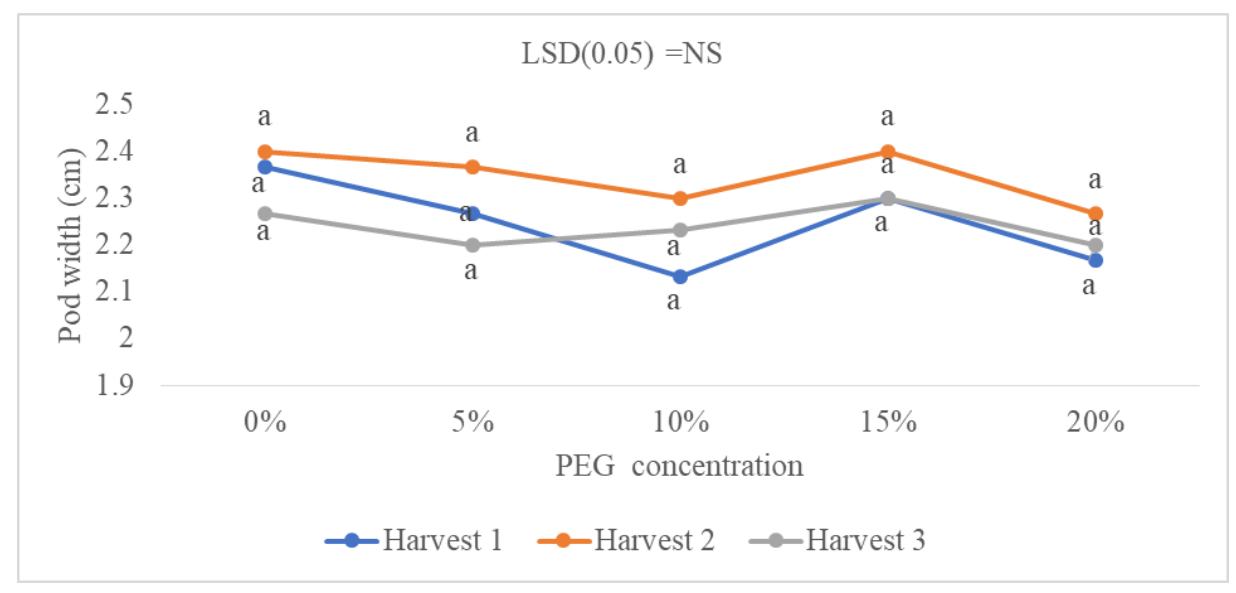

Figure 3 Average pod widths $(\mathrm{cm})$ of okra from the first to third harvests in response to priming with different concentrations of PEG

Means in lines for same harvest followed by the same letter are not significantly different at $5 \%$ level of significance according to Least Significant Difference (LSD) test.

\subsubsection{Green pod yield}

There were no significant differences among the treatments in pod mass at all the three harvests (Figure 4).

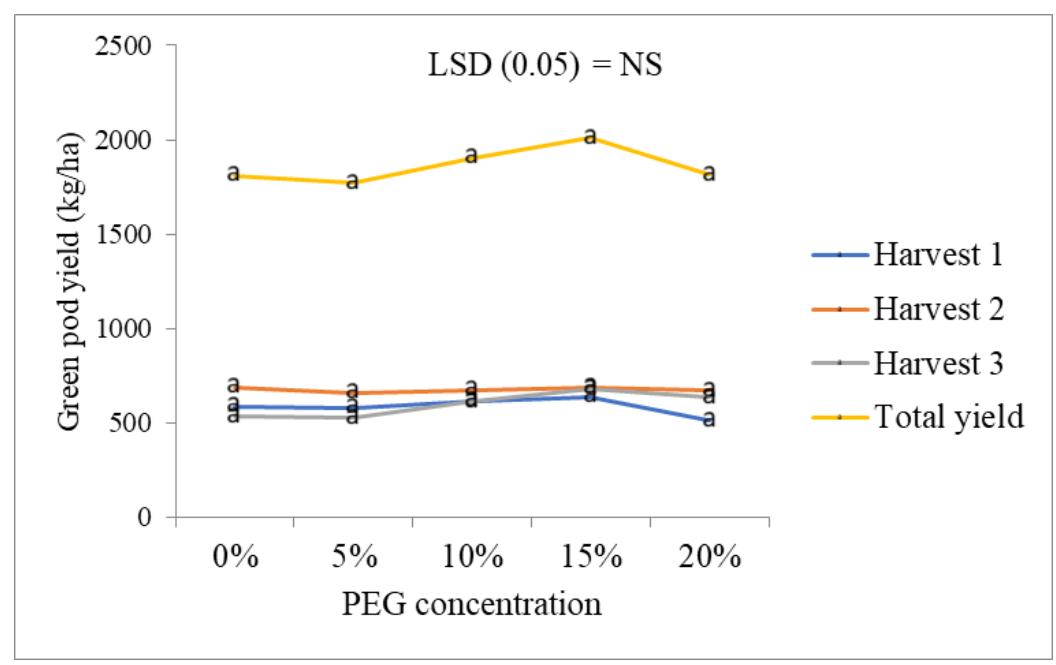

Figure 4 Average green pod yield from the first to the third harvest and total green pod yield of okra in response to priming with different concentrations of PEG 
The pods mass ranged from $511 \mathrm{~kg} \mathrm{ha}^{-1}$ with priming in $20 \%$ PEG at first harvest to $690.7 \mathrm{~kg} \mathrm{ha}^{-1}$ with priming in $15 \%$ PEG at the second harvest (Figure 4). In general, higher pods yield was obtained at the second harvest. Likewise, different priming concentrations of PEG had no significant effect on the total green pod yield of okra (Figure 4). However, plants from seeds primed in 15\% PEG had the highest total green pod (2009.8 $\mathrm{kg} \mathrm{ha}^{-1}$ ) from the three harvests followed by 10\% PEG (1904.2 $\mathrm{kg} \mathrm{ha}^{-1}$ ) (Figure 4).

Means in lines for same harvest and total yield followed by the same letter are not significantly different at $5 \%$ level of significance according to Least Significant Difference (LSD) test.

\section{Discussion}

\subsection{Germination characteristics}

Priming of okra seeds with 15\% PEG significantly increased the germination index and final germination percentage of okra seeds (Table 1). The possible reason for improved germination with priming might be synthesis of proteins and leaching of growth inhibitors [25], repair of deteriorative DNA in seeds and activation of antioxidant enzymes which lower peroxidation in seeds. Moreover, it has been reported that seed priming enhances the production of the enzyme $\alpha$-amylase which plays a crucial role in starch mobilization and provides the embryo with carbohydrates for respiration during germination and seedling growth [26]. In line with this result, Rahman et al. [15] reported that priming with PEG improved percent germination of okra seeds as osmotic potential was lowered from 0 to -1.2 Mpa while further lowering osmotic potential to -1.6 Mpa and below adversely affected germination. Similarly, Zhang et al. [27] reported that seed priming with PEG was effective in improving seed germination and seedling establishment of sorghum under adverse soil moisture conditions through strengthened antioxidant system and increased osmotic adjustment, likely resulting in increased stress tolerance. In contrast, priming okra seeds with PEG was not effective in reducing mean germination time in this study which is in agreement with the result reported by Rahman et al. [15].

\subsection{Growth parameters}

\subsubsection{Number of leaves, leaf area index and number of branches}

The highest number of leaves and leaf area index per plant were recorded in priming the okra seeds with $15 \%$ PEG (Table 2) which might be due to uniform emergence and better seedling vigor and growth of the primed seeds. In agreement with this result, Shah et al. [28] reported that okra seeds primed for 24 h either in diammonium phosphate (DAP) or single super phosphate (SSP) gave higher number of leaves. Likewise, Hegazi [29] obtained higher number of leaves and leaf area per plant of okra with priming in $\mathrm{Na}_{2} \mathrm{HPO}_{4}$ as compared to priming in $\mathrm{MgSO}_{4}, \mathrm{KCl}_{\text {, water and }}$ unpriming. Similarly, priming with $15 \%$ polyethylene glycol produced significantly the highest number of branches (Table 2) which could be due to higher leaf area index resulting in higher photosynthesis and thereby partitioned to more number of branches. In consistent with this result, Hardeep et al. [30] reported that seed priming with $5 \%$ and $10 \%$ PEG produced maximum number of nodes and fruiting nodes of okra on main stem as compared to the unprimed seed. Ullah et al. [31] also reported that priming with micronutrients increased number of primary branches per plant and number of nodes and fruiting nodes on main stem in raya (Brassica juncea).

\subsubsection{Canopy height and length of pod bearing zone}

Seed priming with 15\% PEG produced the highest canopy height and pod bearing zone of okra (Figure 1). The increase in canopy height and pod bearing zone in seeds primed with PEG might be due to enhanced water intake that promoted early establishment and vegetative growth. In agreement with this result, Rahman et al. [15] reported that okra plants grown from seeds primed with PEG or Mannitol solutions at 0 to -1.2 Mpa osmotic potential, had attained maximum canopy height while priming seeds with solution having osmotic potential of -2 Mpa or lower had reduced the canopy height. Arif et al. [32] also reported enhanced absolute growth rate and crop growth rates with increase in PEG concentration from 0 to $300 \mathrm{~g} \mathrm{PEG} \mathrm{L}^{-1}$ water and thereafter decreased.

\subsection{Yield components and yield}

\subsubsection{Pod length and pod width}

Seed priming with 15\% PEG produced the highest pod length and width (Figures 2 and 3). The higher pod length and width with priming in 15\% PEG could be due to better seedling vigor and growth which ultimately partitioned to larger pods. In agreement with this result, Hardeep et al. [30] obtained higher fruit length and fruit width of okra from seeds 
primed with 5\% and 10\% PEG than hydro-priming. Similar results were reported by Saikia et al. [33] who obtained larger ear production in wheat with osmopriming (10\% PEG).

\subsubsection{Green pod yield}

Plants from seeds primed in 15\% PEG produced the highest green pod yield (Figure 4). The higher pod yield might be due to enhanced seedling vigor, improved vegetative and reproductive characters, which ultimately contributed to higher yield. Moreover, primed seeds are developmentally more advanced than dry seeds, resulting in a 'head start of germination' [34]. As a result, seedlings from primed seeds have more developed roots before the common limiting factors such as declining soil moisture, crust formation and/or high salinity prevent successful emergence. In agreement with this result, Rahman et al. [15] obtained maximum fruit yield (14.7 $\mathrm{t} \mathrm{ha}^{-1}$ ) of okra with priming in PEG at osmotic potential of -1.2 Mpa while the minimum yield (12.4 $\mathrm{t} \mathrm{ha}^{-1}$ ) was recorded for unprimed seeds. Likewise, Hardeep et al. [30] reported that okra seed priming with 5\% PEG for $24 \mathrm{~h}$ duration gave better fruit yield and biochemical quality parameters by tolerating adverse environmental effects

\section{Conclusion}

Priming okra seeds with 15\% PEG improved the germination characteristics, growth parameters, yield components and green pod yield of okra. Thus, priming okra seeds in 15\% PEG for 24 hours can be used to increase the productivity of okra in the study area. However, to reach at a conclusive recommendation, the experiment has to be repeated over more years with inclusion of more priming treatments and durations to account for seasonal variations in weather variables.

\section{Compliance with ethical standards}

\section{Acknowledgments}

We thank the Crop Production Department for the provision of well-prepared experimental plots and the necessary materials for the experiment. We are also grateful to Zubuko Dlamini for the technical support.

\section{Disclosure of conflict of interest}

The authors declare that they have no conflicts of interest.

\section{References}

[1] Chadha KL. Hand book of Horticulture, Okra. Indian Council of Agricultural Research. 2002; 427.

[2] Berry SK, Kalra CL, Sehgal RC, Kulkarni SG, Arora SK, Sharma BR. Quality characteristics of seed of five okra cultivars. Journal of Food Science and Technology. 25: 303- 305.

[3] Dilruba S, Hasanuzzaman M, Karim R, Nahar K. Yield response of okra to different sowing time and application of growth hormones. Journal of Horticultural Science Ornamental Plants. 2009; 1: 10-14.

[4] Dinham B. Growing vegetables in developing countries for local urban populations and export markets: Problems confronting small-scale producers. Pest Management Science. 2006; 59: 575-582.

[5] Pandita VK, Anand A, Nagarajan S, Seth R, Sinha SN. Solid matrix priming improves seed emergence and crop performance in okra. Seed Science and Technology. 2010; 38(3): 665-674.

[6] Felipe VP, Antonio AL, Francisco AP. Improvement of Okra (Abelmoschus esculentus L.). Hardseedness by using microelements Fertilizer. Horticulture. 2010; 28(3): 232-235.

[7] Balla MMA, Saidahmed AI, Makkawi M. Effect of moisture content and maturity on hardseededness and germination in okra (Abelmoschus esculentus L. Moench). International Journal of Plant Physiology and Biochemistry. 2011; 3(6): 102-107.

[8] Capron I, Corbineau F, Dacher F, Job C, Côme D, Job D. Sugar beet seed priming: Effects of priming conditions on germination, solubilization of 11-S globulin and accumulation of LEA proteins. Seed Science Research. 2000; 10: 243-254.

[9] Farooq M, Basra SMA, Rehman H, Saleem BA. Seed priming enhances the performance of late sown wheat (Triticum aestivum L.) by improving chilling tolerance. Journal of Agronomy and Crop Science. 2008; 194(1): 5560. 
[10] Pill WG, Necker AD. The effects of seed treatments on germination and establishment of Kentucky bluegrass (Poa pratensis L.). Seed Science and Technology. 2001; 29(1): 65-72.

[11] Chen K, Arora R. Dynamics of the antioxidant system during seed osmopriming, post-priming germination, and seedling establishment in spinach (Spinacia oleracea). Plant Science. 2011; 180(2): 212-220.

[12] Yuan-Yuan S, Yong-Jian S, Ming-Tian W, Xu-Yi L., Xiang G, Rong H, et al. Effects of seed priming on germination and seedling growth under water stress in rice. Acta Agronomica Sinica. 2010; 36(11): 1931-40.

[13] Rahimi A. Seed priming improves the germination performance of cumin (Cuminum syminum L.) under temperature and water stress. Industrial Crops and Products. 2013; 42: 454-460.

[14] Sikhondze DK, Ossom EM. Impact of priming okra (Abelmoschus esculentus L.) seeds on seedling performance in Swaziland. Advances in Environmental Biology. 2011; 5(6): 1221-1228.

[15] Rahman IU, Shamsher A, Mukhtar A, Mohammad A, Hidayat U, Muhammad F, Anwar M, Abdul SS, Mohammad I. Effect of seed priming on germination performance and yield of okra (Abelmoschus esculentus L.). Pakistan Journal of Agricultural Research. 2016; 29(3): 253-262.

[16] Moradi A, Younesi O. Effects of osmo and hyropriming on seed parameters of grain sorghum (Sorghum bicolor L.). Australian Journal of Basic and Applied Sciences. 2009; 3(3): 1696-1700.

[17] Yari L, Aghaalikhani M, Khazaei F. Effect of Seed priming duration and temperature on seed germination behavior of bread wheat (Triticum aestivum L.). ARPN Journal of Agricultural \& Biological Science. 2010; 5(1): 5-8.

[18] Neamatollahi E, Bannayan M, Darban AS, Ghanbari A. Hydropriming and osmopriming effects on cumin (Cuminum cyminum L.) seeds germination. World Academy of Science, Engineering \& Technology. 2009; 57: 526529.

[19] Bujalski W, Nienow AW, Maude RB, Gray D. Priming responses of leek (Allium porrum L.) seeds to different dissolved oxygen levels in the osmoticum. Annals of Applied Biology. 1993; 122(3): 569-577.

[20] Edje OT, Ossom EM. Crop Science Handbook. Blue Moon Publishers, Manzini, Swaziland. 2016.

[21] Murdoch G. Soils and land capability in Swaziland. Swaziland Ministry of Agriculture, Mbabane, Swaziland. 2000.

[22] ISTA (International Seed Testing Analysis). International rules for seed testing. Seed Science and Technology. 2008; 24: 155-202.

[23] Ellis RH, Roberts EH. The quantification of ageing and survival in orthodox seeds. Seed Science and Technology. 1981; 9: 373-409.

[24] GenStat. GenStat Procedure Library Release.18th edition. VSN International Ltd. 2015.

[25] Bray CM, Davison PA, Ashraf M, Taylor RM. 1989. Biochemical changes during osmopriming of leek seeds. Annals of Botany. 1989; 63(1): 185-193.

[26] Farooq M, Hussain M, Nawaz A, Lee DJ, Alghamdi SS, Siddique KHM. Seed priming improves chilling tolerance in chickpea by modulating germination metabolism, trehalose accumulation and carbon assimilation. Plant Physiology and Biochemistry. 2017; 111: 274-283.

[27] Zhang F, Yu J, Johnston CR, Wang Y, Zhu K, Lu F, et al. Seed Priming with Polyethylene Glycol Induces Physiological Changes in Sorghum (Sorghum bicolor L. Moench) Seedlings under Suboptimal Soil Moisture Environments. PLoS ONE. 2015; 10(10): e0140620.

[28] Shah AR, Sajid M, Abdur-Rab Ara N, Ahmad M, Wahid F, Shafi G. Response of germination, growth and yield of okra (Abelmoschus esculentus) to seed priming duration and p-sources in Northwest Pakistan. African Journal of Plant Science. 2011; 5(11): 663-670.

[29] Hegazi AZ. Influence of seed priming on growth and seed yield of okra under water stress. Egyptian Journal of Agricultural Research. 2014; 92(1): 197-217.

[30] Hardeep K, Neena C, Mamta P. Effect of different seed priming treatments and priming duration on biochemical parameters and agronomic characters of okra (Abelmoschus esculentus L.). International Journal of Plant Physiology and Biochemistry. 2015; 7(1): 01-11.

[31] Ullah MA, Sarfraz M, Sadiq M, Mehdi SM, Hassan G. Effect of pre-sowing seed treatment with micronutrients on growth parameters of raya. Asian Journal of Plant Science. 2002; 1: 22-23. 
[32] Arif M, Mohammad TJ, Naqib UK, Ahmad K. Khan MJ Iqbal M. Effect of seed priming on growth parameters of soybean. Pakistan Journal of Botany. 2010; 42(4): 2803-2812.

[33] Saikia TP, Barman B, Ferrara GO. Participatory evaluation by farmers of on-farm seed priming in Wheat in Assam, India. Australian Society of Agriculture. 2006; 37(3): 403-415.

[34] Chen K, Arora R. Priming memory invokes seed stress-tolerance. Environmental and Experimental Botany. 2013; 94: 33-45. 